PART 1

Clientelism and Citizenship 
Emma Porio - 9789004329669

Downloaded from Brill.come4/26/2023 02:14:26PM via free access 


\title{
Citizen Participation and Decentralization in the Philippines
}

\author{
Emma Porio
}

Since the early 1990s, democratization and decentralization have radically changed the functioning of both national and local governments in the Philippines. The Local Government Code of 1992, for instance, reassigned functions and powers that were previously under national agencies to local government units (LGUs). Furthermore, the 1992 Urban and Housing Development Act transferred housing, social services and land use functions to local governments, in attempts to curb the growth of informal settlements and poverty. In addition to this, constitutional and legal reforms have led to a national 'citizen charter' which has enabled citizens and citizen groups to complain to officials whenever the delivery of public services is inadequate. Therefore, the 1989 Constitution gave civil society a more prominent role in policy development.

As a result of these changes, some observers argue that citizens have become more actively engaged with the performance of (local) governments (see, for example, Guevarra 2004; Holmes 2011; Porio 2012, 2014). However, while most studies have hailed this increased citizen participation as a boost for the performance of local governments, some have argued that decentralization has also led to the further entrenchment of traditional elites and their local allies (Rocamora 2003). After twenty years of local governance reforms, and with increased citizen participation through NGOs, community-based organizations (Своs) and people's organizations (POs), many civil society leaders and reform advocates in the Philippines find themselves questioning the prevalence of such predatory and clientelistic practices of the political elites.

Previous studies have argued that the weak institutional apparatus of the Philippine state is responsible for this entrenchment of elite politics (e.g. Rocamora 2003) and further reinforced by the absence of strong political parties (Rivera 2011). These institutional arguments can partly account for the dominance of political-economic elites in local politics. Yet I expand this argument further and state that the mobilization and participation of civil society groups is actually helping local elites to strengthen their dominance. I stress that the new emphasis on citizen participation and accountability has not led to the redistribution of power; on the contrary, the emphasis on civil society participation has actually offered new avenues for 'dynastic' local families to 
develop and nurture local support, further cementing their powerful positions. Unlike earlier political elites, the current breed of politicians have engaged various segments of civil society and the private sector in their implementation of government programmes. In this process, mayors and government officials construct a seemingly accountable, participatory and empowered governance structure by forging collaborative partnerships with civil society organizations and the private sector, while in fact they are reinforcing their political dominance as, in actuality, these partnerships can weaken civil society.

This is done through what I call 'networked governance practices' - the practice of incorporating civil society organizations by giving them a role in city governance (and thus access to budgets of local government units (LGUS)) in exchange for political support during elections. Unlike the earlier centralized period, the above-mentioned governance reforms open up spaces for local chief executives to create legitimate networks and alliances with civil society organizations and the private sector, so that they engage in implementing their priority programmes. Through these mechanisms, the power of the local chief executive (including that of his family and allied social, political and economic networks) is socially produced and reinforced in governance structures and practices.

\section{Democratization and Decentralization}

The decentralization of state power from national to local governments was instituted to increase the efficiency and effectiveness of LGUs in responding to the needs of their constituents. In the Philippines, decentralization ensued alongside the push for democratization of state - civil society relationships, which was given a big boost in the 1986 People Power Revolution (Porio 2002). People Power presumably dismantled the twenty-year Marcos dictatorship, starting with a declaration of martial law in 1972. The push for the decentralization - democratization nexus in urban development became further institutionalized by the Social Reform Agenda (SRA) of the Ramos Administration (1992-1998). The SRA became the centrepiece for institutionalising democratic practices, such as the consultation and participation of marginalized groups and other sectors, in local - national governance processes.

The Citizens Charter, ${ }^{1}$ the main framework for citizen engagement, describes the service standards that citizens can expect from government officials. It provides step-by-step instructions to avail a particular service (for example,

1 Off-shoot of the RA 9485 or the 2007 Anti-Red Tape Law. 
how to obtain birth, death, business and work certificates, or business processing and licensing services) as well as a guarantee of the expected performance level. This aims to reduce resource leakages or corruption and increase inclusiveness in the delivery of social services to the LGUs constituencies, especially those from the marginal groups. Decentralization has resulted in the LGUS gaining more control over state resources, and the allocation/distribution of these public goods, such as the Internal Revenue Allotment (IRA) of LGUS or the income from property taxes, have often become patronage goods that politicians and parties can use to reward or attract supporters.

Researchers have given decentralization and democratization policies mixed reviews. Several authors have sought to highlight their innovations, accomplishments and successes, such as Holmes (2011) and Guevara (2004), whereas others have argued that decentralization has not successfully eliminated the problems of corruption, nor the dominance of political elites and their clientelistic strategies (see Langran 2011; Leviste 2004; Rivera 2011; Rood 1998). These authors have argued that decentralization has given much greater autonomy and control to local chief executives, which can sometimes compromise the delivery of basic services as well as reproduce local patronage structures. But others (such as Karaos 1997) have argued that these reforms have expanded the autonomy and participation of citizen groups or civil society in both national and local governance.

My argument is partly at odds with this assessment, and I stress that the current emphasis on democratic governance is actually strengthening their dominance of the local political. Their 'networked governance strategies' enable political elites to present themselves as implementing democratic reforms, whilst also building their electoral support. They selectively strengthen traditional political elites and allied power bases in civil society and the business sector by granting them a role in the provision and organization of public services. Ironically, these clientelistic practices are legitimized within a discourse emphasizing the importance of civil society and democracy in crafting development trajectories. In this process, these exchanges strengthen political elites in power and their allied partners in civil society and the private sector, while eroding the influence of competing political patrons in the city. This emerging pattern in decentralized governance also raises the contradictory tendencies of civil society participation in local governance - that of broadening citizenship bases while, at the same time, narrowing and strengthening certain lines of participation and reinforcing/consolidating the power bases of the ruling political elite.

I will illustrate these arguments by examining the implementation of environmental programmes in Pasig City and the urban renewal programme in Mandaluyong City, which are two of the richest areas of Manila (Virola 2010). 
As mentioned by Holmes (2011), these two cities have been awarded the Galing Pook Awards for excellence in local governance.

\section{A Case Study: Mandaluyong City's Urban Renewal Programme for Welfareville}

Metro Manila, or the national capital region (NCR), is the political, sociocultural and economic centre of the country and often referred as 'Imperial Manila' by political leaders outside of it. Accounting for over one-third (38\%) of the nation's gross domestic product (GDP) and being the seat of political power, this label is not entirely misplaced. ${ }^{2}$ However, economic growth and investments in basic services and infrastructure have not kept abreast with the expanding needs of the population. ${ }^{3}$ Decentralization of urban governance and management, then, becomes a critical factor in how local government units (LGUS) can provide basic services, stimulate the economy and generate employment for its constituencies (Porio 2009; NCSB 2010).

Metro Manila comprises seventeen administrative cities, each having relatively autonomous local government units (LGUS), but is loosely connected through the Metro Manila Development Authority (MMDA), which takes care of traffic, waste management and flood control functions. Pasig and Mandaluyong are two of them. Urban renewal, disaster management, population control, delivery of services, health, sanitation and environmental functions are the responsibility of the LGUs, but also constitute a major challenge for the metropolis. With the devolution of these functions, local chief executives (LCE) or mayors have executive, legislative and judicial control over local officials, government employees and their political constituencies.

Mandaluyong City has a total population of 328,700 , spread across twentyseven barangays ${ }^{4}$ (NSCB 2010) and is one of the top fastest growing cities in Metro Manila. Located at the geographical centre of the metropolis, Mandaluyong is bordered by the country's capital in the West, San Juan City (North),

2 With a population of 12.5 million in an area of 686 square kilometres, Metro Manila is highly congested at 18,650 residents per square kilometre With only 3.5 million in 1970, the city's population expanded almost four times over the past forty years and is projected to reach twenty-five million in 2020.

3 While Metro Manila's poverty incidence is lower (11\%) compared to the national figure $(33 \%)$, one in every ten residents live in slum and squatter settlements (Ballesteros 2010) and about $60 \%$ do not have adequate basic services.

4 Lowest political-administrative unit of the Philippine government. 
Quezon City and Pasig City (East) and by Makati City (South). It hosts the huge commercial complex of the Ortigas Center, the Asian Development Bank (АDB) and the Philippine office of the World Bank and other UN agencies. While it has only a $2.5 \%$ poverty incidence, it houses one of the most congested informal settlements in Manila - the Welfareville community. This sees 23,000 informal settler families (about 161,00o people with 55,000 registered voters) all crammed into a twenty hectare lot. Aside from being highly congested, a large segment of the population does not have adequate access to potable water, sanitation facilities and jobs/livelihoods. A sizeable portion of the community also gets flooded during rainy seasons as they do not have adequate drainage systems, especially those living near the creeks and danger zones.

Although enacted in 2007, the Citizen's Charters of Pasig City and Mandaluyong City were only approved in 2010 due to civil society pressure. The mayors of both cities are quite proud of the impacts of the charter to their services provided to their constituents. Some city officials, however, admitted that they do not fully comprehend their Citizen's Charter (Honasan 2012) - a pattern quite common among local officials (Saguin 2012). ${ }^{5}$ The Citizen's Charter, however, only serves as a basis for demanding services that are already operational as it does not include strategic policy decisions on public goods, such as housing, land and environmental resources. Nevertheless, the implementation of Citizen's Charters has led to community groups and private sector demanding better implementation of both policies and programmes.

Governance of Mandaluyong City for the past twenty-six years, has rested mainly on the two political clans of Mayor A and Congressman G (see Figure 2.1). This is affirmed by the voting patterns and list of winners obtained from the Commission on Elections. While incumbent officials in other places (such as India) have not maintained their stronghold in local politics, those in Metro Manila have been able to do so, in part because of their implementation of networked governance practices detailed here.

The mayors of Metro Manila tend to make themselves highly visible before their constituencies through their local programmes. Aside from the payment of taxes and fees, commercial and industrial establishments have to obtain or renew their business licenses and licenses to operate, among others, which need the approval or signatures of the mayor, other officials and/or civil servants. The business license plates - nailed to the wall of every business establishment as evidence of its legitimate operations - in most cities in Metro Manila have a picture of its mayor and the city. And no less than twenty

5 Personal communication with Marivel Sacedoncillo, director of the Local Government Academy affirmed this pattern. 
Case Box 1. The A and G Political Families in an LGU in Metro Manila

A. Sr. (Officer in Charge) ${ }^{*}: 1986-1987$

Mayor A Sr. (1988-1991; 1992-1995; 1995-1998)

Mayor A1 (son): 1998-2001; 2001-2004

Mayor NG (close party mate): 2004-2007 (was Congressman in 20072013) Mayor A1 (son): 2007-2010; 2010-2013

Mayor NG: became mayor in 2013 elections while mayor Aı became congressman

Since 1986, the A and G families have just exchanged their political positions when their allowed terms expire (3 year terms are allowable).

*Appointed by Pres. Corazon Aquino after People Power in 1986;

appointed by Pres. Arroyoto chair of Metro ManilaDevelopment Authority (2001-2002); appointed COMELEC Chair in 2002 until his resignation in 2007 due to allegations of corruption.

FIGURE 2.1 Political genealogy of local chief executives in Metro Manila: The A and $G$ political families in an LGU in Metro Manila.

SOURCE: COMPILED BY THE AUTHOR.

signatures are needed from the city hall and other regulatory agencies for, for example, the conversion of a residential lot to a commercial-industrial one.

And there are yet other ways for the mayor to make himself visible and influential. His picture is almost always appended to every service vehicle of the local government, every programme supported and every activity/event of which he is a major guest or supporter. ${ }^{6} \mathrm{~A}$ good example are the billboards announcing the time to pay taxes. A reminder to business establishments that their support is very crucial for the services provided by the city (police, social services, health, education, et cetera). Alongside this announcement are also the names of all the officials who constitute his 'dedicated service team' for his people. This is one way of 'aligning' other officials to support the mayor's political line of service, which can be viewed by all the citizens.

6 Because politicians and government officials alike have fully mobilized the potential of communication resources (tarpaulin banners, brochures, bulletin boards, texting, LGU website, et cetera) to 'plaster' their faces in public domain spaces, they have witnessed a recent backlash. Even President Aquino has criticized some public officials for using people's taxes to finance their political propaganda. Transparency International, an $\mathrm{NGO}$, has initiated a campaign (Anti-EPAL) against this common practice among public officials, whether elected or not, to append their faces/names to public-funded services and programmes. 
Often, these 'business processes' become spaces for aligning establishments and groups to become partners of the mayor's priority programmes. During key events, organizers from the community and private sector would often request that the mayor or his representative be the guest of honour. This is, in part, to assure themselves to be 'on the good side' of the LCE and his allied officials/staff. These spaces, in turn, also become 'negotiating points' for special favours by businessmen and community leaders who might need 'support from city hall' with their operations.

This kind of clientelistic personalism seems to inform many transactions between the LCE and local leaders and citizen groups as will become apparent when we delve further into the everyday execution of the Urban Renewal Program of Welfareville. As mentioned earlier, Mandaluyong ranks sixth among Metro Manila's wealthiest cities, but it also houses the most congested urban poor settlement in the city - the Welfareville Community.

To improve the area, the local government created the Urban Poor Affairs Office (UPAO) and the Welfareville Commission, which was heavily supported by the city's health and social work and development units. Alongside this, the mayor created the Urban Renewal Programme (URP) in Welfareville to address the problems of poverty, lack of security of tenure and inadequate social services. The programme has mobilized all government, civil society and private sector resources to: (1) ensure security of land tenure for the urban poor families; (2) generate support for social housing from national government sources; (3) enhance the capabilities of NGOS/CBOs in conducting social preparation and continuous cooperation of the people's organizations and of the community; (4) establish mechanisms for сво empowerment towards participatory governance; and (5) work for a more meaningful principled partnering with NGOs, the private sector and other sectors. ${ }^{7}$

To meet the above objectives, the URP partnered with NGOs/POs and business groups in a variety of ways: (1) continuous updating of the listing of informal settler families (ISFs), (2) securing the safety of neighbourhood blocks by ensuring that no outsiders can build housing in the area; (3) mobilizing resources from government and business partners; (4) mobilizing savings amongst the neighbourhood blocks; (5) formulating a comprehensive land and housing development plan for Welfareville. Factors integral to these strategies include community preparation and organization, education and capacity-building (training, seminars and workshops provided by the programme), participation of all stakeholders in the projects, and networking and establishing linkages with other interested sectors. These integral

7 From the programme description. 
components of 'empowerment' are part and parcel of the programme, and include setting in place systems of monitoring and sustaining it. Likewise, control mechanisms, such as against squatting and squatting syndicates, are installed and institutionalized in collaboration with the Cвоs, the NGOs, the police, the private sector and church groups (see figure 2.2 below). This is continually reinforced by the programme's advocacy work and continuing development of its staff, and the mobilization of the beneficiary communities' savings, and is monitored regularly from the Welfareville Commission, the Urban Poor Affairs and the Office of the Mayor. One major victory for these governance networks, after years of demolition threats, saw the mayor bring the DSWD secretary (property custodian of the national government) to a Town Hall meeting before 4,00o Welfareville residents in October 2011, convincing the latter to agree that people shall never be moved under them. After this, they posted several signages (displaying their names and faces) in

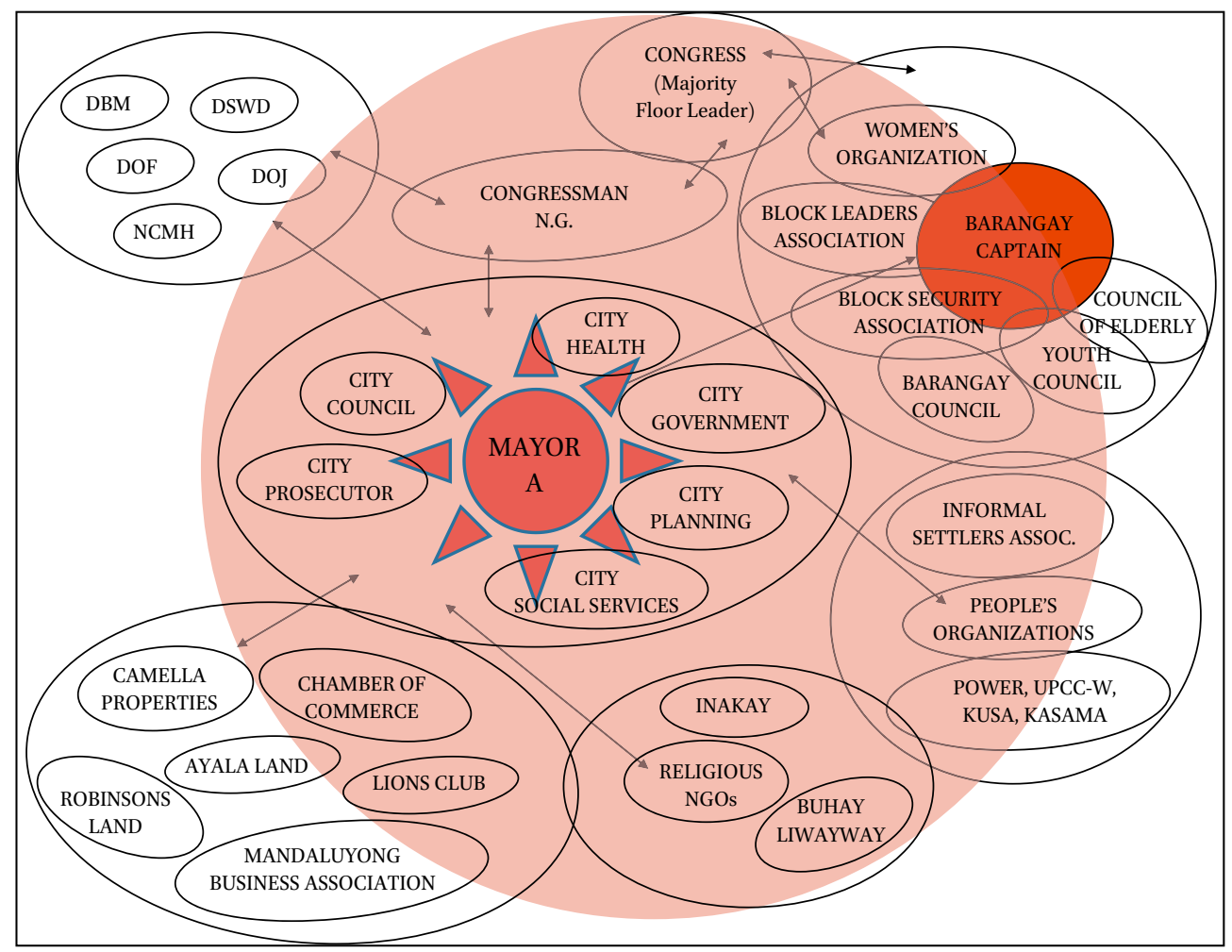

FIGURE 2.2 Networks of partner NGOS/POs, business and government in the Urban Renewal Programme in Mandaluyong City.

SOURCE: COMPILED BY THE AUTHOR. 
public places around the city, assuring their constituents in Welfareville that, while they are serving as leaders, the informal settlers will not face danger of being relocated, nor will their houses be demolished.

The key point here is that these different partnerships are not just strategies to improve governance, but that they also facilitate political mobilization during elections. Thus, the building and control of 'vote banks', like that of Welfareville during elections, is all part of the networked governance strategy that the mayor of Mandaluyong has employed to construct his political clientelism. The people in Welfareville represent a major 'vote bank' of mayor A2, who has belonged to one of the ruling political families for the past twentysix years in Mandaluyong City. In almost all local elections since 1987, both father and son have always captured about $90-95 \%$ of the community's vote. These votes have been maintained over the years because of positive transactions and exchanges between the community and the city hall officials. To fully understand how this is articulated in the urban renewal programme of Welfareville, let us examine below the governance networks of the city mayor in relation to the barangay governance of the community (see figure 2.3 below).

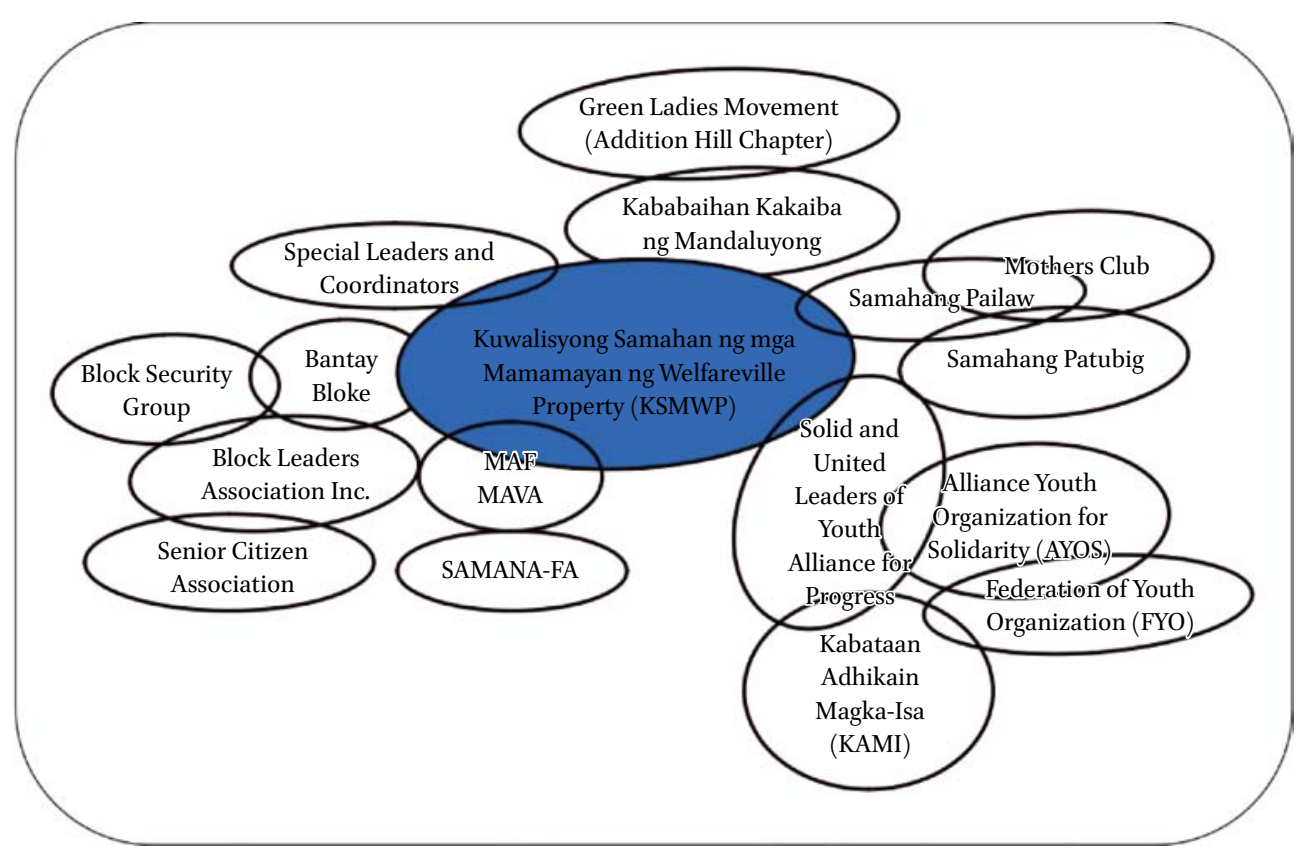

FIGURE 2.3 Allied networks of NGOs and community-based organizations (cBOs) associated with the mayor's Urban Renewal Programme in Welfareville. SOURCE: COMPILED BY THE AUTHOR. 


\section{Privileged Access to Services}

The appropriation of community associations and engagements by mayors, along with citizen groups and csos, has also been selectively instrumentalized by the constituent groups themselves in Welfareville. The residents are quite aware of their 'contribution' to the mayor's continuing hold of power in local governance and their votes during elections. Several community leaders asserted: 'We in Welfareville contribute the biggest chunk of the vote for the mayor. He needs us, so when we ask for something, he does not hesitate to give it to us'. From their point of view, it is a mutually beneficial relationship, with their leader providing 'security' from being evicted by the landowner (national government agency) and rallying behind them to obtain housing security and social services like water, health and basic education. 'Madali naming malapitan ang aming mayor tungkol sa mga pangangailangan namin. Sabi niya hindi niya kami pabayaan na maalis kami dito. Tulungan niya kami sa paglalaban naming para magkaroon kami dito ng sariling tirahan!' (We can easily approach the mayor for our needs. He told us he will never allow us to be evicted from here; he will help us in our struggle to own this land!). These were their assertions during the community mobilizations initiated by Welfareville residents before the City Hall, in protest of the national governments' move to sell the property and relocate residents outside the city. Clearly, citizen groups here treat their local leaders as protectors from external assault by, for example, the national government or realtors/developers.

Furthermore, these partnerships help the mayor construct the impression with his constituency that the provision of public services is due to his help, as local organizations can use their newly acquired political links to solve bureaucratic hurdles. These above partnerships, especially those with marginalized groups, are also accompanied with incentives/rewards, such as easier access to services, government resources and casual employment, and support of the mayor and other local officials. Correspondingly, there are also disincentives (such as non-recognition or non-approval of their participation or of their activities) for those who are not very cooperative (non-alignment with political objectives of the LCE or non-support for its flagship programmes, for instance).

In particular, the functioning of the barangay, the local government unit, can illustrate how access to public services is highly politicized and traded for electoral support. One example regards the way in which people acquire government-recognized ID. To obtain this, one must first apply for a barangay clearance, which firstly needs certification of being a resident and, secondly, requires proof of being a good citizen of the community from the barangay captain. Clearances from the barangay and the National Bureau of 
Investigation are also required for employment applications and any formal transactions with institutions. Barangay clearances released to residents are written on a letterhead and include the names of the mayor, barangay captain and his officials.

Barangay leaders mobilize their connections with the mayor to negotiate the implementation of urban renewal programmes to determine, for example, housing designs and beneficiary upgrades. These urban renewal negotiations in the community are very much interwoven with the provision of social services and security. Discussions and decisions about these issues are often taken up during weekly/bi-monthly meetings of the community-based organizations (e.g. block security brigade, block leaders brigade, youth/women's/ senior's council, et cetera) which are held alongside other community sociocultural events (such as monthly sports-fest, health or community fair) and political events (e.g. executive, legislative and judicial sessions of the barangay council) that provide a good excuse to invite the mayor or his representative to honour their event or programme.

A second example of the clientelistic exchange of services for support regards the organization of social and security services (water, health, police, et cetera). This is prepared through several community organizations such as the bantay bloke or neighbourhood watch group, water block group, women's/ youth group, mothers club, senior citizens group, anti-drug campaigns by youth groups and senior citizens, et cetera). These groups regularly receive 'gifts' of resources from the mayors' and barangay captain's social services fund (for example, ham for all senior citizens during Christmas, birthday cakes for all those born in Welfareville, gift packs and assistance for all the block leaders and sectoral leaders, et cetera. About these gifts, the barangay captain will say, 'This is how our leader really cares for us!' But these organizations are actually mobilized by community leaders and residents alike to ask for services and assistance, especially during emergencies, from the mayor and city hall officials. In exchange, these organizations form the backbone of election campaigns as they help to spread the word about the mayor's support for ordinary people like them. One resident told the author: 'I was so touched that our mayor helped me with the hospital expenses of my mother; considering how busy he was, it touched me even more that he took the time to help me'. Supporters provide such testimonies during campaign sorties and political meetings in the barangay hall or town plaza. They help organize house-to-house campaigns of the mayor and his party. More importantly, while performing their community duties, they serve as the mayor's 'eyes and ears' and report on developments that may affect the mayor's political fortunes in their locality. 
These exchange relations illustrate how good governance indicators (accountability, transparency, efficiency/effectiveness, community participation and empowerment, innovation, sustainability) have been taken up by local chief executives to enable the strengthening and elaboration of clientelistic networks through which they can mobilize particularly marginal communities. As the case study from Pasig will also illustrate, city mayors have strategically appropriated or instrumentalized the strategies and discourses of good governance - engagement of civil society actors in governance routines and collaboration with private sector - to fulfil their need of building up networks that can facilitate a clientelistic exchange of access to state resources for political support.

\section{A Second Case Study: Pasig City's Greening Programme}

Pasig City, one of the oldest cities of the Philippines, ranks fourth in terms of economic GDP and demographic growth in Metro Manila. Located approximately twelve kilometres east of Manila, its area is sprawled along the banks of the Marikina and Pasig rivers, with the Napindan Channel draining towards Laguna Lake. Given its environmental location, flooding in the city has caused much damage to property, as well as death/injuries among the residents, thereby greatly hampering the city's economic growth. The flagship programme of the mayor, the Pasig Green City Programme, is crucial for the city's development.

The city, as shown in figure 2.4 below, has been politically controlled by one family in particular since the early 1990s.

For most local chief executives, their vision for the city will factor in that of the mayor, including existing governance strategies. When mayor RE Jr. unveiled the Pasig Green City Programme before a large assembly and the

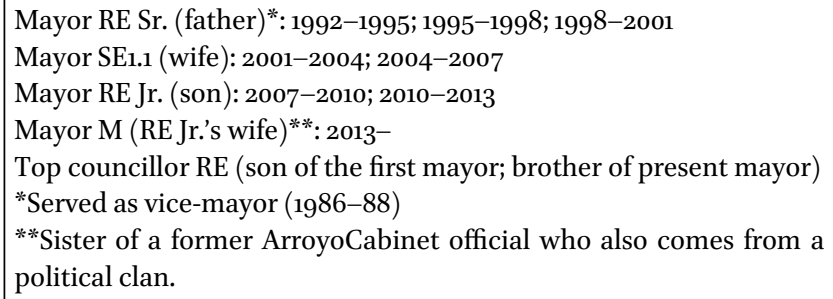


media, he envisioned the city to be 'a progressive city with clean air, a safe and healthy environment, where there are lush urban forests and green spaces', moving 'towards a more ecologically sound community of empowered Pasiquenos through a constituent-responsive leadership'. He, then, challenged the citizen's assembly before him 'to join, participate and support me in creating a paradigm shift in governing the city'. He called upon the citizens to adopt the motto, 'Beyond progress; A healthy environment', and used multisectoral and multidisciplinary approaches to implement it. In this comprehensive programme, climate change (e.g. GHG Inventory, management and accounting) and all other environmental programmes were integrated to the social, economic and development programming of the city. The mayor gave his 'visioning speech' in 2009, after Typhoon Ketsana submerged $70 \%$ of the city for several days/weeks, giving him an excellent rationale for his flagship programme, along with the City Environment and Natural Resources Office (cenro). He then deputized the cenro and the Pasig Command, Communications and Control Centre (Pasig $\mathrm{C}_{3}$ ) to be the key arm in implementing his environmental programmes. The latter office has been purposely organized by the mayor as the nerve centre for directing and coordinating traffic, emergency and disaster situations and the focal point for counter-emergency and/ or disaster plans.

Pasig $\mathrm{C}_{3}$ brings together all aspects of communication, information, warning and alerting of residents, situation assessment and monitoring and overall coordination of initiatives towards an environmentally-safe and -sound city. It also serves as a communication link to other service units provided by the city government, such as social services, public safety and order, traffic management, environmental services and public information with a 24/7 emergency monitoring operation. It has various system components in order to perform its functions: (1) computer telephony interface; (2) computer-aided dispatch with GIS capability; (3) centralized communication console Motorola command lite; (4) geo-mapping system; (5) GPS vehicle monitoring readiness; (6) research and manpower database; and (7) road management monitoring. Pasig $\mathrm{C}_{3}$ collaborates with CENRO and the Pasig Search and Rescue Unit, which has the following programme components: (1) earth and landslide search and rescue course to all communities; (2) barangay cluster emergency teams; (3) rescue training programmes with public/private schools and business establishments; and (4) a safety inspection and building emergency evacuation plan for Pasig for every building and establishment within the city.

Central to the mayor's community organization and mobilization approach is the engagement of community volunteerism. Thus, all the mayors' environment programmes, implemented through the City Environment and Natural Resources office (CENRO), employed the following governance strategies: 
1. The community-based volunteer groups like the Green Police and the Tanod Sapa (Creek Security). There are currently approximately six hundred volunteers from thirty barangays or communities.

2. They organized the Environmental Brigade, and the Bantay Ilog (river watch) from the thirty barangays of the city.

3. They enacted environmental ordinances and strict enforcement of laws, requiring all establishments to secure an Environmental Permit to Operate prior to the issuance of a Business Permit and to install anti-pollution devices.

4. They have effected a recycling and livelihood programme in partnership with schools and parents' associations and private establishments.

5. They implemented massive greening and anti-pollution programmes in partnership with своs, NGOS and the private sector.

This community volunteerism served to address the city's high unemployment, or underemployment rate, among the informal settlers living along the river banks and creeks. Volunteers, called Green Police and River/Creek security, receive meal and clothing allowances (or a cash equivalent of 2,500 Philippine peso, about 60 us dollar per month). As such, they have been deputized to apprehend violators of environmental laws and ordinances of the city government. When queried, the volunteers explained: 'Sinusuwelduhan kami at nagkaroon ng karapatan sa bayan name na magpuna sa kapwa' (We have now salaries and have the right to reprimand our neighbours when they are not observing environmental ordinances!'). These functions have allowed them to become powerful 'eyes and hands of the mayor.' In practicality, these community volunteer brigades have become a sort of semi-casual employee of the city hall through the courtesy of the executive office. Their 'appointment' as volunteers is co-terminus with the mayor's term, but these volunteer groups have also organized themselves into people's organizations in their respective communities with support from environmental NGOs, civic groups and national agencies like the Department of Natural Resources or the Pasig River Rehabilitation Commission, et cetera. These same volunteer groups, alongside NGO and private sector partners, are also mobilized during regular community assemblies, multisectoral consultations and forums organized by the LGU. Thus, the mayor's programmes have successfully engaged the cooperation of networks of actors from NGOS/CвOS/POs, business-related associations, and professional organizations. They have also forged partnerships/linkages with

8 Personal interview with Raquel Austria-Naciongayo, CEnRo officer of Pasig City. 
agencies from national government and quasi-government organizations to make their environmental governance more efficient and effective. But these 'volunteer' spaces have also become 'transactional or negotiating points' for the citizen groups active in these areas to ask for budget allocations for their community activities or for access to resources for their families (for example livelihood and health services). 'Kasi tumutulong kami sa kanya, Itong grupo naming tinutulungun din ng mahal na mayor naming kung may hinihiling kami sa kanyang tulong, halimbawa additional budget para sa aming daycare center, o, tulungan makapasok ang anak ko sa trabaho at iba pa' (Because we help him, our beloved mayor always helps us when we ask for help, say additional budgets for our day care centre, or my son's reference for his factory work, et cetera). In short, the collaborative partnerships crafted here become arenas for exchange of resources.

The linkages of the governance actors and networks active in the local governance of Pasig City can be seen in the graphs below (figures 2.5 and 2.6):



FIGURE 2.5 Pasig Green City Programme and its social map of power sites. SOURCE: COMPILED BY THE AUTHOR. 


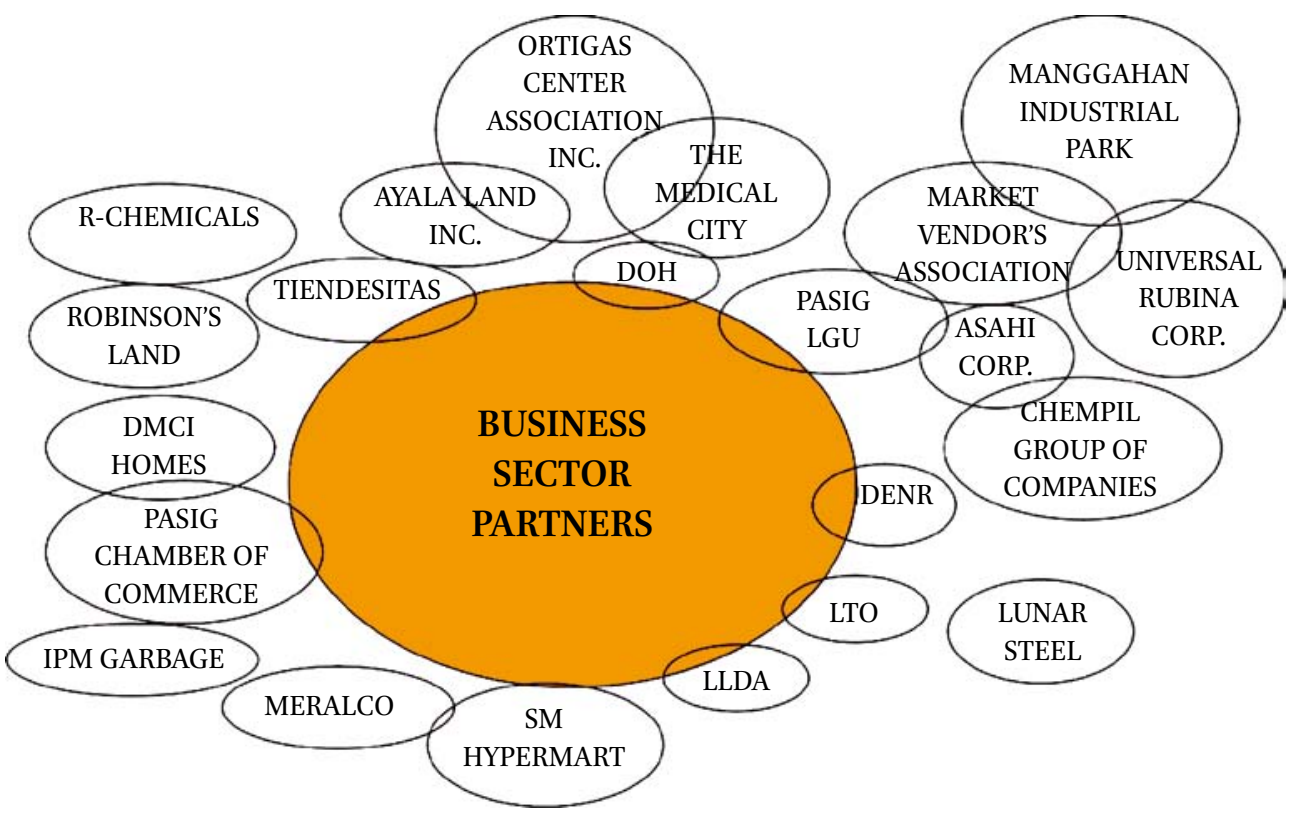

FIGURE 2.6 Networks of business partners in Pasig City's environmental governance. SOURCE: COMPILED BY THE AUTHOR.

Increased resource access by local chief executives under a decentralized regime has empowered them to engage organizational networks in formulating and implementing his priority programmes. Thus, the creation of networked governance structures by LCES have contributed greatly to the persistence of the same power holders in this city. These graphs show the intersections of actor networks mobilized by the mayor and his offices to achieve the goals of local autonomy and development. By doing so, they also perpetuate the control and power of their families in local politics.

\section{Summary and Conclusions}

How is it that, despite the democratization of local governance in the Philippines, predatory politics and clientelism still persist? This article has argued that one answer to this question lies in the way in which government interaction with civil society enables political elites to strengthen their dominance. Studies of decentralization and democratization in the Philippines have often highlighted how local governments and officials construct collaborative engagements with civil society (NGOs/POs/CBOs) and the private sector in policy-making and implementation of their key programmes. In large part 
these strategies have engaged citizen groups to participate in the governance of their cities and localities, but these citizenship engagements and practices have been recasted by political dynastic families to strengthen and further entrench their control and power over local governance. As seen in the above case studies, the relationships and patterns of engagement between both government and non-government actors have indeed become more decentralized, transparent, consultative and participatory. However, local political elites instrumentalize these interactions to create horizontal and vertical networks with NGOs and своs (especially from the marginal sectors) and the private sector in a way that generates a dependent and clientelistic relation. In this sense, LCEs have successfully re-constituted old formations (such as Своs) to make them align and support their programmes, whilst also providing support during elections. Their success in mobilizing these groups can be largely contributed to their continuing dominance in local politics. The employment of networked governance strategies by local chief executives from dominant political and economic elite families allows them to govern their constituents in a seemingly very participatory, transparent, accountable and effective manner, yet they continue to maintain a political stronghold over them.

These governance strategies do not seem to be perceived as predatory, clientelistic and appropriative by these partners because their own interests and goals are also achieved by these collaborative relationships. In the context of a state that is difficult to access, these governance networks serve citizens to obtain privileged access to certain state resources. Citizen groups outside of these networks often complain about the tendencies of these arrangements to exclude others, who are critical of the government, from being able to partake in the distribution of programme-related resources.

Traditional power elites, such as the mayor and the dominant political families of Mandaluyong City/Pasig City in Metro Manila, are able to use democratization and decentralization to their own advantage by employing what I termed 'networked governance strategies'. These strategies consist of the following four elements:

1. Community participation and empowerment effected through consultation, dialogue, and community assemblies with marginalized groups (e.g. the urban poor, street children, homeless people, et cetera) and the creation of opportunities for citizens to 'volunteer' as guardians of the environment (such as the green police) or of public safety (like the Block/ Neighbourhood Watch).

2. Crafting tripartite partnerships with NGOs/CвOs/POs and the private sector in policy formulation and/or project/programme implementation through participatory planning processes, starting from the community 
and linked to other communities through the municipal-wide consultation and planning assemblies. These partnerships gain the capacity to engage in the formulation of local regulatory frameworks, policy-making and implementation of their programmes.

3. Enabling members of these partnerships to gain privileged access to state resources (as citizens) or permits and licenses (for private sector partners).

4. In exchange, civil society leaders use their local prominence to support the election campaign of the mayor and mobilize people to attend rallies and ceremonies during these campaigns.

Decentralized and democratic governance practices like consultation, public hearings, participation and consensus-building are used to generate horizontal and vertical networks of allied NGOS/C BOs and private sector groups. While these groups are rewarded by increased access to state resources, they nevertheless become embedded into a subservient patron - client relationship.

Yet, the networked governance strategies of local governments in the Philippines have really transformed the hierarchical and bureaucratic relationships of local officials with citizen groups and other non-government actors. As seen in the cases above, the LGU officials' networking, negotiation, bargaining systems and coalitions have incorporated non-government actors into the formulation of local regulatory frameworks, policy-making and the implementation of their flagship programmes. Thus, these collaborative arrangements and negotiations have increased the capacity of some civil society groups to shape the implementation of government programmes. The emerging shifts, then, in the locus of power within and across local governance structures, demand that we pay attention to the social production of power of these interactions and networks, dominated by political families in alliance with groups in civil society and the private sector. These practices seem to remind us of the earlier forms of political clientelism, while the discourse of participation and democratization has made the continuation of clientelistic practices appear more legitimate. While these create potential spaces for repositioning or recalibrating the locus of power, they could actually become the engine for reproducing and further mobilizing power in networks already dominated by political families, which have become 'democratized' because of their collaborative partnerships with key leaders from civil society and the private sector. In this sense, the twin forces of decentralization and democratization have simply made it more possible for the local chief executive to systematize the construction of power sites with politically aligned networks of support and reinforce his dominance in local politics. 


\section{References}

Ballesteros, M.M. (2010). Linking poverty and the environment: evidence from the slums in Philippine cities (Discussion Paper Series No. 2010-33). Makati City: Philippine Institute for Development Studies.

Guevara, M. (2004). The Fiscal Decentralization Process in the Philippines: Lessons From Experience. Hitobashi Journal of Economics, 41(2), 97-109.

Holmes, R. (March, 2011). The curious cases of civil society and decentralization. Paper presented at the Philippine Social Science Forum on Decentralization and Governance, Philippine Social Science Center, Quezon City.

Honasan, S. (2012). Failon Ngayon: Citizen's Charter. Retrieved January 26, 2016, from http://news.abs-cbn.com/current-affairs-programs/og/10/12/failon-ngayon -citizens-charter.

Karaos. A.M (1997). Urban Governance and Poverty Alleviation in the Philippines. In E.Porio (ed.), Urban Governance and Poverty Alleviation in Southeast Asia: Trends and Prospects. Quezon City, Metro Manila: Center for Social Policy and Public Affairs, Ateneo de Manila University.

Langran, I.V. (2011). Decentralization, democratization, and health: the Philippine experiment. Journal of Asian and African Studies, 46(4), 361-374. doi: 10.1177/0021909611399730.

Leviste, E.N.P. (2004). Bounded pluralism: politics and participation in health policymaking. Philippine Sociological Review, 52(1-4), 37-54.

National Statistical Coordination Board (NSCB) (2010) Interactive Statistics. http:// www.nscb.gov.ph/activestats/psgc/municipality.asp? muncode $=137601000 \&$ regcod $\mathrm{e}=13$ \&provcode $=76$. Accessed September 8, 2012.

Porio, E. (2002). Urban Poor Communities in State-Civil Society Dynamics: Constraints and Possibilities for Security of Tenure in Metro Manila. Asian Social Science Journal, 3o(1), 73-96.

Porio, E. (2009). Shifting spaces of power in Metro Manila. City: analysis of urban trends, culture, theory, policy, action, 13(1), 110-119.

Porio, E. (2012). Decentralization, Power and Networked Governance Practices in Metro Manila, Space and Polity, 16(1), 7-27.

Porio, E. (2014). Climate Change Vulnerability and Adaptation in Metro Manila: Challenging Governance and Human Security Needs of Urban Poor Communities. Asian Journal of Social Science, 42(1-2), 75-102.

Rivera, T. (2011). Philippine elections and political parties and democratic accountability, 1986-2010. Paper presented at the Philippine Social Science Forum on Decentralization and Governance, Philippine Social Science Center, Quezon City.

Rocamora, J. (2003). The Constituent Assembly Is Dead: Elect Concon Delegates in 2004, Philippine Daily Inquirer, January 25. 
Rood, S. (1998). Decentralization, democracy, and development. In D.G. Timberman

(Ed.), The Philippines: New Directions in Domestic Policy and Foreign Relations. New York: Asia Society.

Saguin, K. (2012). Implementing the Citizen's Charter Initiative in the Philippines: Insights from Selected LGUs. Paper presented in the National Conference of the Philippine Society for Public Administration, Development Academy of the Philippnes.

Virola, R. (2010). Statistically Speaking. http://www.nscb.gov.ph/headlines/StatsSpeak/default.asp. 